\title{
Evidence for enhanced primary production resulting from relative vorticity induced upwelling in the Catalan Current*
}

\author{
TIMOTHY C. GRANATA ${ }^{1}$, MARTA ESTRADA², ULRIKE ZIKA ${ }^{1,3}$ and CAROLYN MERRY ${ }^{1}$ \\ ${ }^{1}$ Civil \& Environmental Engineering and Geodetic Science, Ohio State University, Columbus, OH 43210-1275, USA. \\ E-mail: granata.6@osu.edu \\ ${ }^{2}$ Institut de Ciències del Mar (CMIMA-CSIC) Passeig Marítim de la Barceloneta 37-49, 08003 Barcelona, Spain. \\ ${ }^{3}$ Aquatic Ecology Laboratory, Ohio State University, Columbus, OH 43212, USA.
}

\begin{abstract}
SUMMARY: In baroclinic fronts, jets and eddies, potential vorticity, $P=(\varsigma+f) / D$, connects horizontal motions of planetary vorticity, $f$, and relative vorticity, $\varsigma$, to vertical transport through increases and decreases of the water column height, $D$. In this paper we present evidence that positive changes in relative vorticity of the SW flowing Catalan Current and meandering of the coastal jet follow the $500 \mathrm{~m}$ isobath and are associated with topographic steering by offshore canyons. Generally, positive relative vorticity is a result of cyclonic torque that generates cyclonic flow causing the water column to upwell since both $P$ and the volume of the flow are conserved. With coastal jets that flow over abrupt topographies, such as deep canyons, $D$ increases and flow must take on a cyclonic circulation, favoring upwelling conditions. In the case of a westward flowing current, we would expect the flow to acquire a cyclonic vorticity upstream of the canyon but to enter at the canyon obliquely (Cushman-Roisin, 1994) causing downwelling. Upwelling in meandering coastal jets can also occur when horizontal streamlines diverge, unable to adjust to relative vorticity changes, and fluid parcels near the edge of the front separate. Using pycnocline thickness as an indicator of $D$, we show that deep canyons stretch the water column causing cyclonic meandering (positive relative vorticity), upstream of the canyon during the FRONTS cruises 1991 to 1993 . This phenomena has been shown to cause upwelling upstream of meander troughs (Onken, 1992) which in this case would mean upstream of canyons. We hypothesize that the increased relative vorticity, associated with upwelling in the pycnocline, fuels episodic primary production across the front accounting for more than $30 \%$ of the new production in this coastal zone.
\end{abstract}

Key words: vorticity, meanders, Catalan Current, new production, primary production.

RESUMEN: EVIDENCIA DE UN AUMENTO DE LA PRODUCCIÓN PRIMARIA DEBIDO AL AFLORAMIENTO INDUCIDO POR LA VORTICIDAD EN LA CORRIENTE CATAlana. - En los frentes baroclínicos, los chorros y los remolinos, la vorticidad potencial, $P=(\varsigma+f) / D$, conecta los movimientos horizontales de la vorticidad planetaria, $f$, y de la vorticidad relativa, $\varsigma$, con el transporte vertical mediante aumentos y disminuciones de la altura de la columna de agua, $D$. En este trabajo presentamos pruebas de que los cambios positivos en la vorticidad relativa de la Corriente Catalana, que fluye hacia el SW, y la formación de meandros del chorro costero, siguen la isobata de $500 \mathrm{~m}$ y están asociados con la dirección topográfica definida por los cañones submarinos. Por lo general, la vorticidad relativa positiva es el resultado de un momento torsor ciclónico que genera un flujo ciclónico que provoca que la columna de agua aflore puesto que tanto $P$ como el volumen del flujo se conservan. Con chorros costeros que fluyen sobre topografías abruptas, tales como cañones profundos, $D$ aumenta y el flujo tiene que adoptar una circulación ciclónica, lo que favorece las condiciones de afloramiento. En el caso de una corriente que fluye hacia el oeste, esperaríamos que el flujo adquiriera una vorticidad ciclónica aguas arriba del cañón, pero que entrara oblicuamente en éste (Cushman-Roisin, 1994), provocando hundimiento. También puede darse afloramiento en chorros costeros que forman meandros cuando las líneas de flujo horizontal divergen, incapaces de ajustarse a los cambios de vorticidad relativa, y cerca del borde del frente se separan bloques de fluido. Utilizando el espesor de la picnoclina como indicador de $D$, demostramos que los cañones profundos extienden la columna de agua provocando formación ciclónica de meandros (vorticidad relativa positiva) aguas arriba del cañón, durante las campañas FRONTS de 1991 a 1993 . Se ha demostrado que 
este fenómeno causa afloramiento aguas arriba de los caballones de meandros (Onken, 1992), lo que en este caso significaría aguas arriba de los cañones. Emitimos la hipótesis de que el aumento de vorticidad relativa, asociado con el afloramiento en la picnoclina, genera producción primaria episódica a través del frente que explica más del 30\% de la producción nueva en esta zona costera.

Palabras clave: vorticidad, meandros, Corriente Catalana, producción nueva, producción primaria.

\section{INTRODUCTION}

Within the NW basin of the Mediterranean Sea, a permanent density front occurs between the Balearic Islands and the Iberian mainland (Salat and Font, 1987; La Violette et al., 1990; López García, 1991; Estrada, 1993). The front is oriented NE-SW and is the demarcation between the shoreward Catalan Current, flowing to the southwest, and the offshore Balearic Current, flowing to the northeast (Salat and Font, 1987; Castellón et al., 1990). The position of the front is seasonally variable and controlled by wind and density distributions over the shelf. The latter is dependent on river discharge, which normally peaks in the spring (Font et al., 1990, Salat et al., 2002). The Catalan current is a coastal jet within the front. The front is a prograde, meaning that it intersects the bottom shoreward of its intersection with the surface; thus it does not reside over any specific isobath. The front is often associated with elevated subsurface levels of chlorophyll-fluorescence and phytoplankton production relative to waters east and west of the front (Estrada, 1979, 1982, 1993; Estrada and Salat, 1989; Estrada et al., 1993). While it has been suggested that frontal processes produce local upwelling of nutrients enhancing phytoplankton biomass and production in the front (Estrada and Margalef, 1988; Zakadjian and Prieur, 1998), no physical mechanism has been proposed to account to for this phenomena in the Catalan front. Yet given the rough topography of this coastline and the tendency of coastal jets to follow isobaths, the mechanism of relative vorticity driven upwelling may be an important mechanism driving production in the Western Mediterranean Sea. The critical meander scale for topographic steering of the current can be estimated from the relationship

$$
K=\frac{\Delta H f}{U h} \text { (Cushing-Roisin, 1994), }
$$

where $K$ is the length scale of curvature of the current of velocity $U, h$ is water column depth, and $\Delta H$ is the change in depth over the canyon. For the canyons along the Catalan coast, $U \approx 15-30 \mathrm{~cm} \mathrm{~s}^{-1}$,
$\Delta H \approx 500 \mathrm{~m}, f \approx 10^{-4} \mathrm{~s}^{-1}$ and $h \approx 10^{3} \mathrm{~m}$ resulting in a $K \approx 7-14 \mathrm{~km}$. This is the nominal width of several canyons along the coast, meaning that flow over canyons would respond to canyon topography. The second condition for topographic steering is that the baroclinic shear must not reduce the total flow, and thus increase $K$ such that only large canyons would affect the meandering. In this paper we address these criteria for meandering to test the hypothesis that high levels of phytoplankton biomass and production are a result of positive changes in relative vorticity along the front as it meanders.

\section{METHODS}

During the FRONTS cruises of 1991, 1992, and 1993, CTD profiles were taken over a grid of hydrographic stations that spanned the frontal system (Fig. 1). Transects were perpendicular to the coast and stations were roughly $6 \mathrm{~km}$ apart along the transects. A Sea Bird CTD equipped with a Sea Tech fluorometer was used for the 1991 cruise and an Endeco dissolved oxygen (DO) sensor was added for the 1992 cruise. A Mark V CTD with fluorometer and DO was deployed for the 1993 cruise. CTD parameters were vertically resolved to $10 \mathrm{~cm}$. CTD thermistors were calibrated to temperature in the field and the salinity and DO were calibrated from in situ water samples. Fluorescence was calibrated against extracted chlorophyll and DO was corrected for temperature. Water samples for primary production measurements were taken every $10 \mathrm{~m}$ from the surface to $70 \mathrm{~m}$. Primary production was measured using incubations with ${ }^{14} \mathrm{C}$ in light and dark bottles (Estrada, 1993). Density, areal chlorophyll-fluorescence and areal dissolved oxygen (DO), were derived from profiles of temperature, salinity, chlorophyll-fluorescence, and DO respectively. The thickness of the pycnocline, $D$, was calculated as the depth between the 28.2 and $28.8 \mathrm{~kg} \mathrm{~m}^{-3}$ isopycnal surfaces. Areal chlorophyll-fluorescence and DO were integrated from 5 to $140 \mathrm{~m}$ to account for the majority of the phytoplankton biomass and produc- 


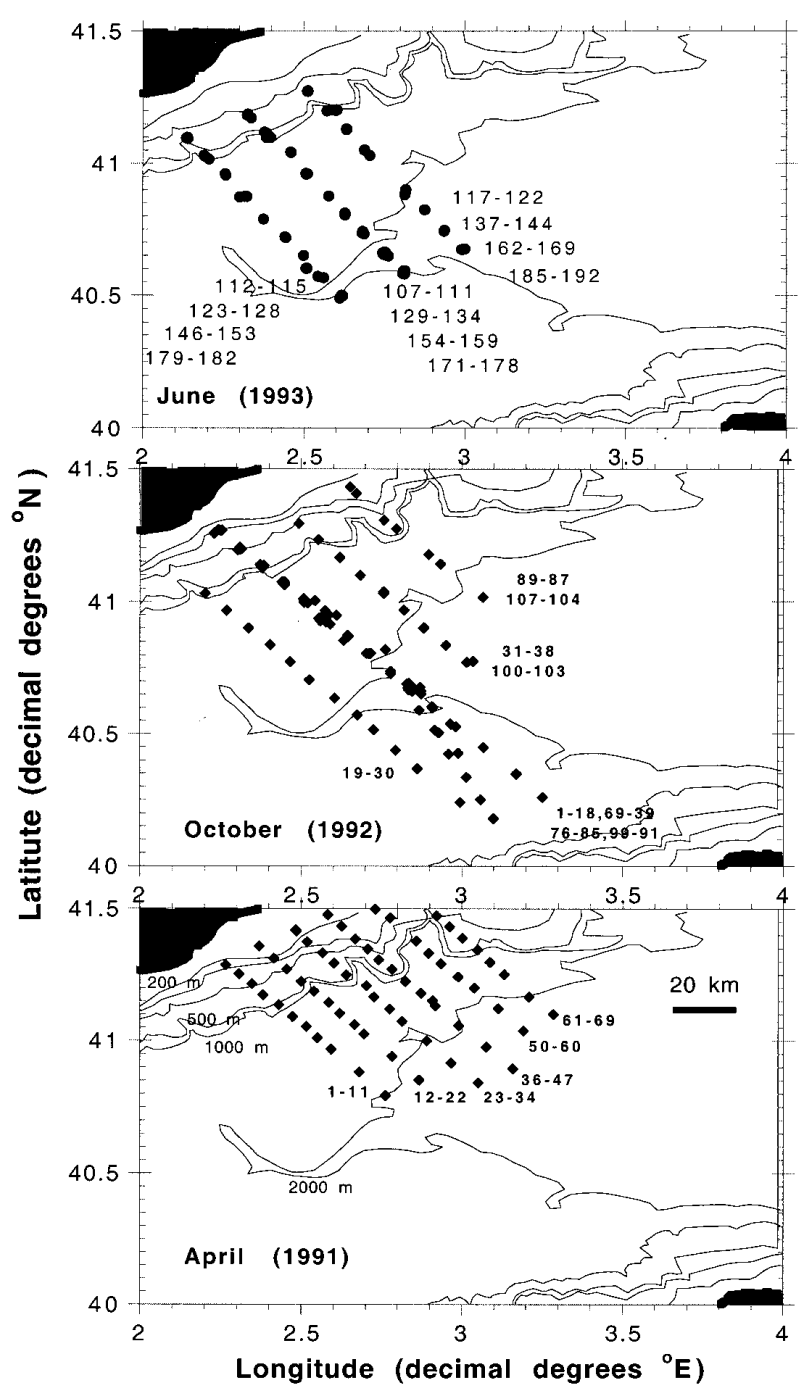

FIG. 1. - Hydrographic stations during the FRONTS 1991-1993 cruises, covering spring through autumn seasons. Bathymetry is denoted as solid lines in meters.

tion in the euphotic zone. We chose to integrate over the euphotic zone to achieve a conservative estimate of community production given that respiration can be higher than production at depth. This technique also eliminates aliasing of the vertical signal (Wiggert et al., 1999) since the entire euphotic zone is used and not only a part which may or may not have included the vorticity change. Offshore cross-sections of sigma-t and chlorophyll-fluorescence concentrations have been contoured to elucidate the vertical structure of the physical and biological variables. The number of stations with nutrient data was not sufficient to provide cross-sectional distributions. Multiple passes over the same transect were temporally grouped to produce continuous grids for the 1992 and 1993 data sets. Maps of biological and physical parameters were spatially weighted using a krigging routine and plotted using Surfer software.

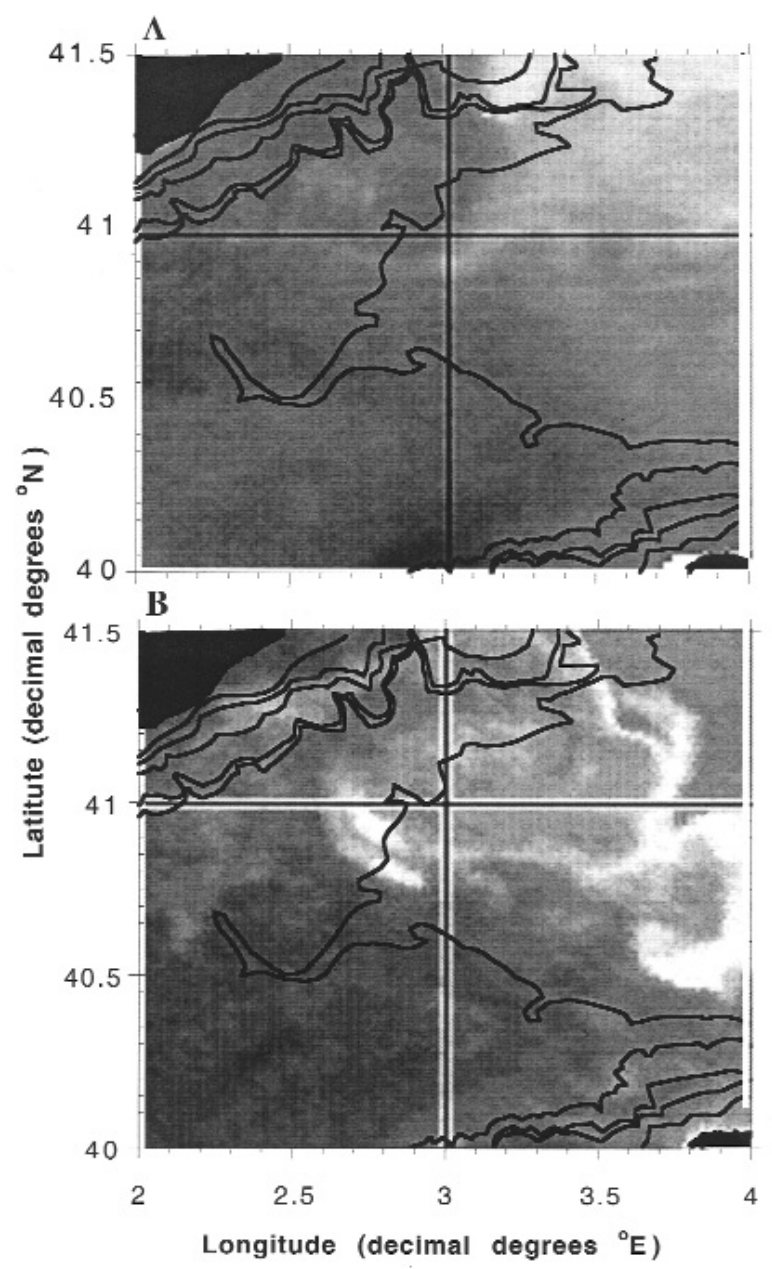

FIG. 2. - Development of a density front over a 22 day span illustrated in relative sea surface temperatures on July 16 and August 7, 1998. Near the coast, the front meanders along the $500 \mathrm{~m}$ isobath.

Although velocities were measured continuously along transects using an acoustic Doppler current profiler (ADCP), data were unreliable as a result of gaps in GPS ship position. As a consequence of the lack of velocity data, potential vorticity, in terms of $D$, is used to infer meandering of currents. To demonstrate the spatial extent and evolution of the frontal system, coastal bathymetry was superimposed on geometrically corrected images of relative sea surface temperature (SST). The advanced very high resolution radiometry (AVHRR) satellite images of sea surface temperatures (SST), downloaded from the ADIOS website, had a spatial resolution of $1.1 \mathrm{~km}$.

\section{RESULTS}

Sea surface temperatures indicate frontal systems of the Catalan current are associated with coastal 


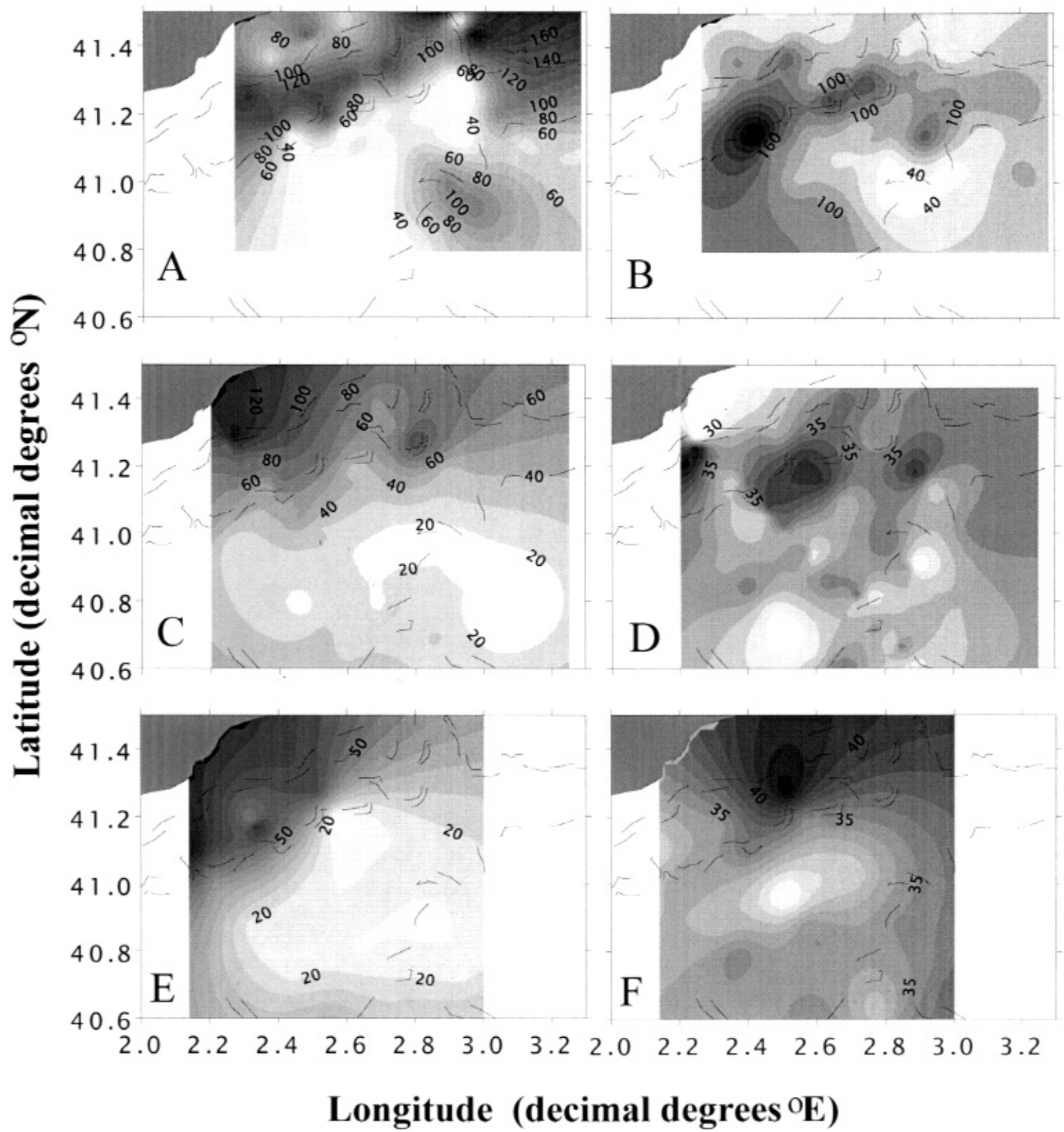

FIG. 3. - Contours of pycnocline thickness, $D$ (m, at left), and areal chlorophyll-fluorescence ( $\mathrm{mg} \mathrm{m}^{-2}$, at right) for spring (A and B), summer (C and D), and autumn (E and F).

topography which induce current meanders over the shelf (Fig. 2). Evidence of potential vorticity changes in the current are illustrated as variations in the thickness of the pycnocline, $D$, that tracked the $500 \mathrm{~m}$ isobath (Figs. 3A, C, E). For the SW flowing current, positive relative vorticity (i.e. cyclonic motion) corresponded to regions of increased pycnocline thickness, $D$, implying upwelling zones. Upwelling and plankton biomass were most pronounced in the spring, decreasing through the summer and autumn (Figs. 3B, D, F). In spring, high values of $D$ (upwelling) occurred upstream of the meander troughs and low values of $D$ (downwelling) downstream of the troughs. Maxima areal phytoplankton biomass also tracked the $500 \mathrm{~m}$ isobath, except in the most northeastern section of the grid where data were sparse. Chlorophyll-fluorescence distributions in summer and autumn generally followed the same trends as in spring but with lower magnitudes. DO presented similar patterns (Fig. 4). Offshore crosssections of density and chlorophyll-fluorescence distributions illustrate the doming of the density sur- 


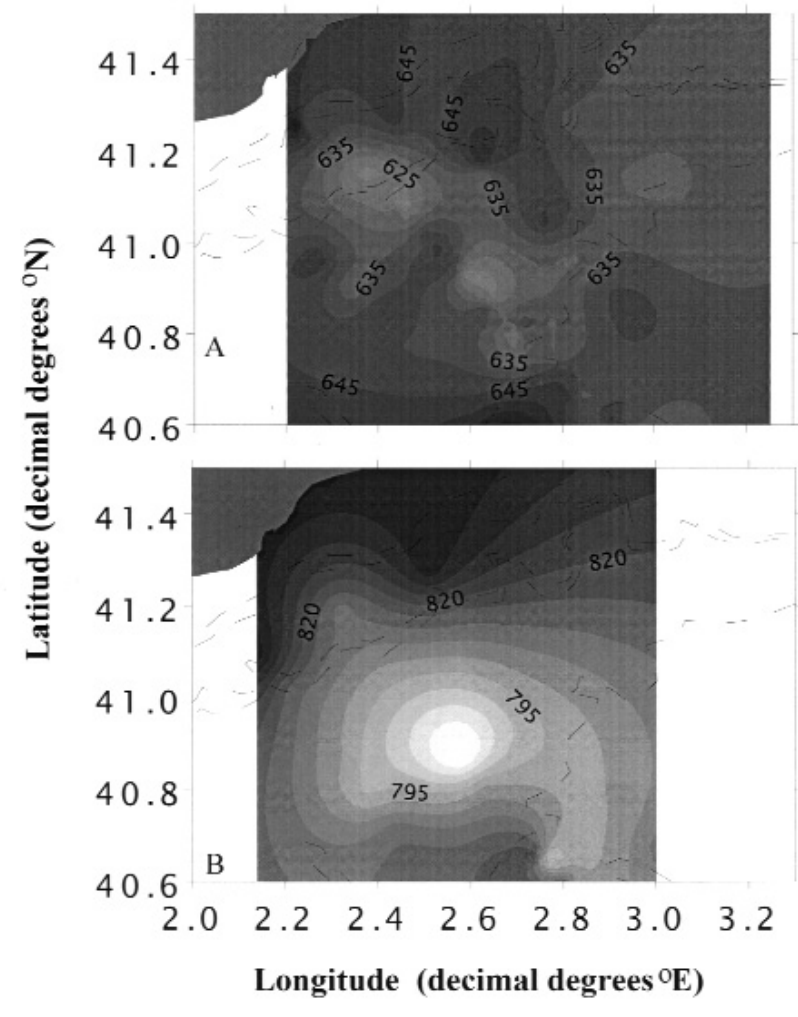

FIG. 4. - Contours of areal dissolved oxygen, DO $\left(\mathrm{mg} \mathrm{m}^{-2}\right)$, for the summer (top) and autumn (bottom) cruises. DO was not measured during the spring cruise.

faces at the front and the subsurface chlorophyll-fluorescence maximum in the pycnocline (Fig. 5). These plots also show the seasonality of the density field with intense stratification occurring from the summer through late autumn, as the mixed layer deepened. In contrast, the peak in chlorophyll was manifest in the spring. Dynamic heights, which illustrate the position of the flow, clearly indicate that the larger canyons can steer the flow over the canyon

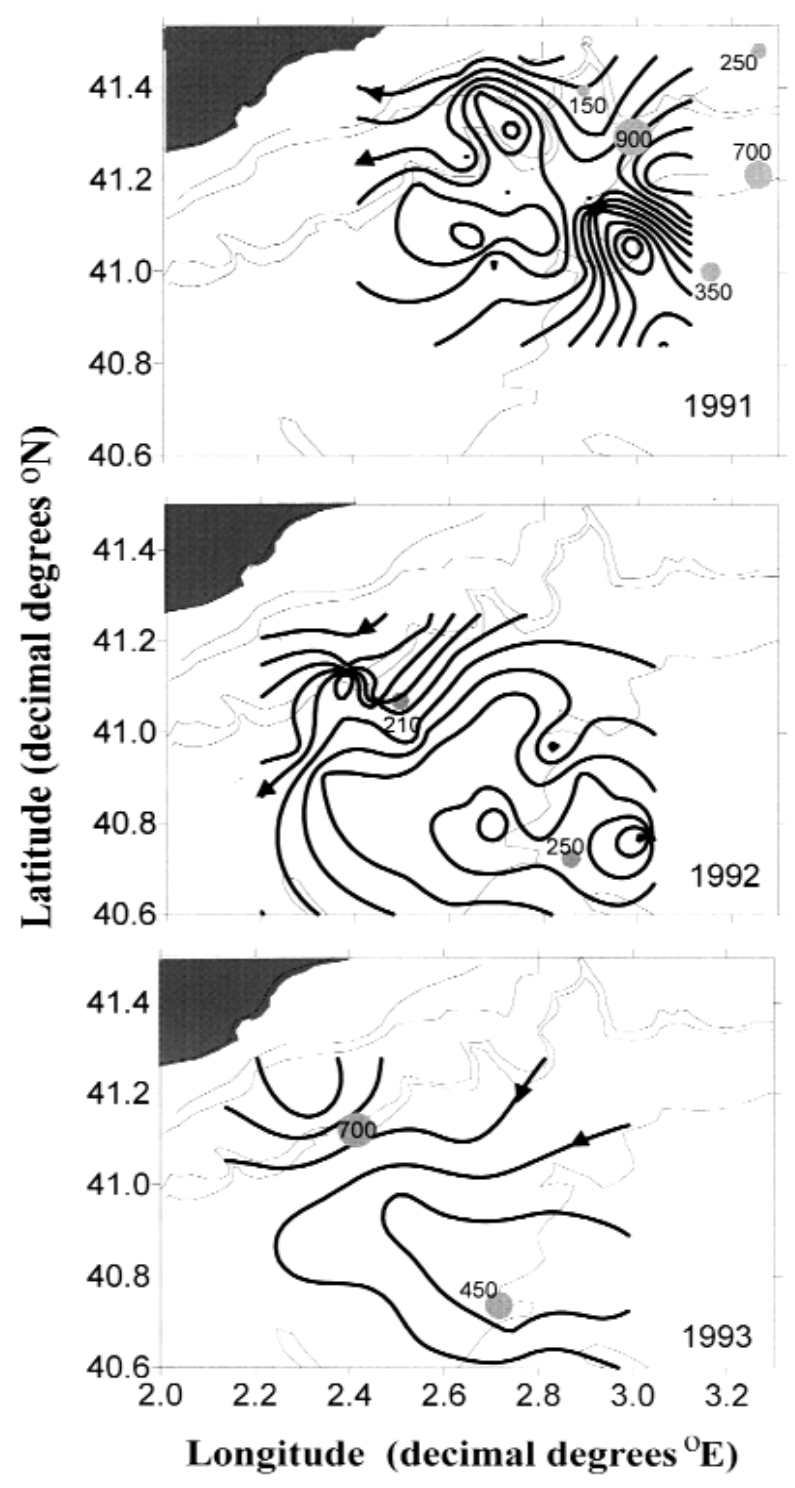

FIG. 6. - Maps of dynamic height at $50 \mathrm{~m}$ referenced to $400 \mathrm{~m}$ for1991, 1992 and 1993. The size of circles plotted over dynamic heights indicate the rate of primary production $\left(\mathrm{mg} \mathrm{C} \mathrm{m}^{-2} \mathrm{~d}^{-1}\right)$.
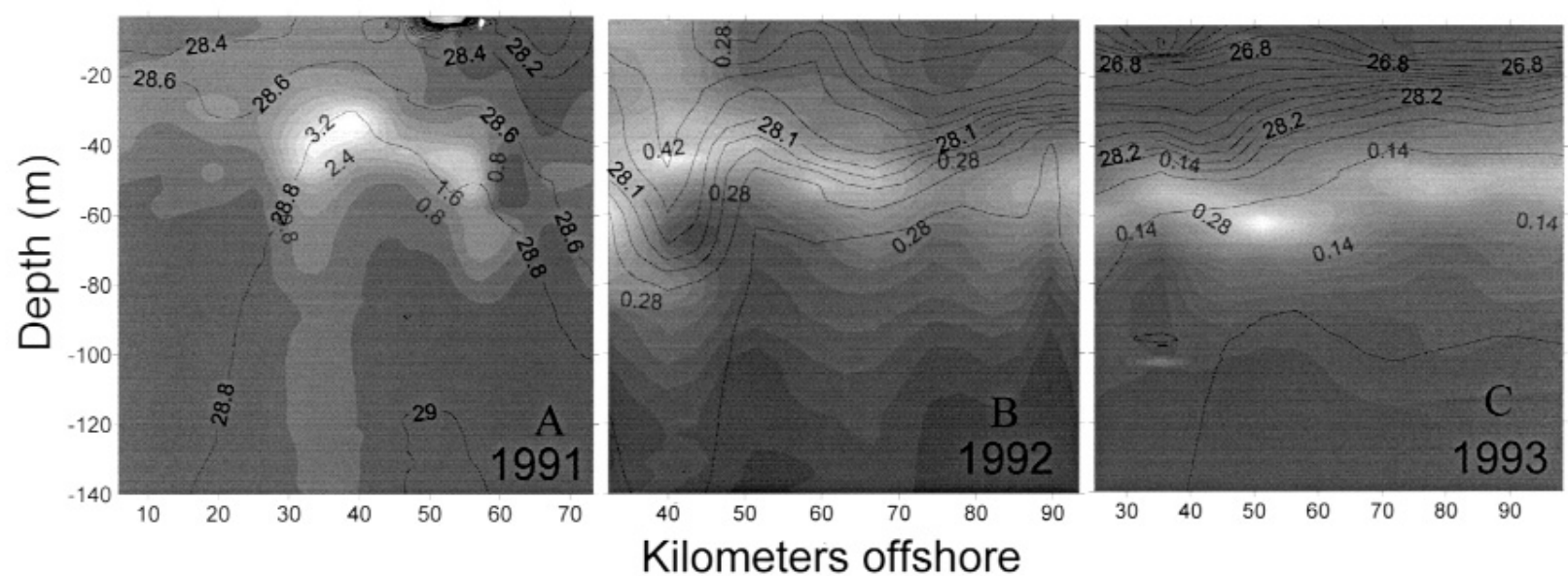

FIG. 5. - Cross-sectional contours of sigma-t (isolines, $\mathrm{kg} \mathrm{m}^{-3}$ ) and chlorophyll-fluorescence (increasing with decreased shading, $\mathrm{mg} \mathrm{m}^{-3}$ ) for spring (A: stations 50-60), summer (B: stations 31-38), and autumn (C: stations137-144). 
(Fig. 6) and account for the upwelling inferred from figure 3. In 1991, an increase in primary production was associated with this upwelling (between stations 56 and 67) with values from $150 \mathrm{mg} \mathrm{C} \mathrm{m}^{-2} \mathrm{~d}^{-1}$ in the canyon (station 54) to $900 \mathrm{mg} \mathrm{C} \mathrm{m}^{-2} \mathrm{~d}^{-1}$ just upstream of the meander trough and upstream of the canyon between stations 56 and 67, supporting the hypothesis that this new production may be enhanced by a positive change in relative vorticity. Enhanced production in the other seasons is less evident.

\section{DISCUSSION}

Both sea surface temperatures and in situ data indicate the front has a tendency to meander along the $500 \mathrm{~m}$ isobath. The tendency of the southwest flowing current to veer toward the coast, following the isobath shoreward, produces a cyclonic relative vorticity that results in vortex stretching and increased values of $D$. Conversely, as the isobath curves offshore, the coastal front becomes anticyclonic resulting in vortex shrinking and decreased pycnocline thickness, D. Masó et al. (1990) and Masó and Tintoré (1991) have shown that the topographically driven front is an extensive feature along the Catalan coast. Current vectors over similar topography to the north of our site in the summer of 1993 clearly demonstrate that the positive vorticity region was associated with the $500 \mathrm{~m}$ isobath (see Fig. 3, Olivar et al., 1998). As Font et al. (1995) point out, frontal activity decreases from spring to summer. Furthermore, Salat et al. (2002) have demonstrated that density distributions and flow patterns vary significantly during mesoscale events and are more seasonal occurrences. Such modified density distributions may result in flow reversals over canyons (Rojas et al., 1995). This is consistent with prominent April (1991) vortex stretching which is reduced in summer when stratification intensifies. It should be noted that unlike the grid in spring (April 1991), the grids in the summer and autumn were not optimally spaced to fully resolve topographic meanders. For instance, in June 1993, the grid only covered one offshore excursion of the $500 \mathrm{~m}$ isobath. This reduced spatial resolution most likely aliased distributions of the physical and biological parameters.

The evidence of pycnocline stretching (and shrinking) suggests zones of upwelling (and downwelling) which we did not measure but do infer from values of $D$, and areal distributions of chlorophyllfluorescence and DO. Numerical studies of relative vorticity changes in meanders have shown that pycnocline stretching is accompanied by upwelling upstream of meander troughs (Onken, 1992; Pinot et al., 1996) and support our hypothesis of new production driven by topographic steering. The most direct evidence of upwelling would have been to measure the vertical velocity component of the flow. Yet even with the most advanced current meters, in all but the most dynamic fronts, vertical velocities are nearly impossible to resolve from a moving ship. Vertical velocities, however, can be calculated using ageostrophic corrections (Pinot et al., 1996), provided that horizontal velocities are accurately measured. Since velocity measurements in this study were unreliable, future efforts should emphasize improving ADCP data acquisition especially in the canyons. Unfortunately, the best Doppler current measurements rely on bottom tracking, which does not penetrate to the bottom in deeper canyon reaches. One solution is to combine measured currents, over the shelf, with derived currents in the canyons (Granata et al., 1999). A higher spatial resolution of the hydrographic grid would also be invaluable for visualizing meanders around abrupt topographic features along this coast. Finally, real time measurements of nutrients and primary production can now be made on the same time scales as temperature and salinity measurements, and in the future will be invaluable for resolving episodic production on fine spatial scales.

Theoretical studies have demonstrated that positive vorticity in a $20 \mathrm{~km} \mathrm{x} 20 \mathrm{~km}$ meander would induce an average vertical velocity of $4 \mathrm{~m} \mathrm{~d}^{-1}$ (Onken, 1992; Pinot et al., 1996). Based on a concentration of $6 \mathrm{mg} \mathrm{P} \mathrm{m}^{-3}$ below $200 \mathrm{~m}$ (Estrada and Margalef, 1988), upwelling water would transport $24 \mathrm{mg} \mathrm{P} \mathrm{m}^{-2} \mathrm{~d}^{-1}$. Given a C:P ratio of 40:1 (Estrada and Margalef, 1988), the rate of primary production would equal $960 \mathrm{mg} \mathrm{C} \mathrm{m}^{-2} \mathrm{~d}^{-1}$ (which is similar to the value measured near the canyon between stations 56 and 67 in 1991). The fact that canyons are prevalent along the western Mediterranean coastline means this mechanism may integrate over large parts of the coast. However, upwelling events are probably seasonal and episodic, depending on the strength of the current system, making such a high level of primary production ephemeral. Still, a $1 \mathrm{~m}$ x $20 \mathrm{~km}$ slice through a zone with active upwelling over 30 days per year could inject $14 \mathrm{~kg}$ P. This would represent about $30 \%$ of the new production calculated by Estrada and Margalef (1988) for a $1 \mathrm{~m}$ wide band, approximately perpendicular to the coast, and some 
$200 \mathrm{~km}$ in length. Onshore-offshore distributions of larval fish have also been linked to topographically induced transport (Alvarez et al., 1996; Olivar et al., 1998; Sabatés et al., 2001). These motions and associated phytoplankton production might also explain the seasonal recruitment of fish larvae along the coast (Zika, 1999).

Our goal has been to present a plausible mechanism for sustaining high levels of production and forcing new production in the NW Mediterranean Sea. Other mechanisms that may contribute to upwelling and new production across fronts include isopycnal mixing (Pinot et al., 1995; Zarardjian and Prieur, 1998), convergence of filaments (Tintoré et al., 1990; Wang et al., 1999), and inertial wave breaking in anticyclonic regions (Salat et al., 1992; Granata et al., 1995). Future research along the Catalan coast should discern if one of these other mechanisms or the mechanism of vorticity enhanced production described in this paper, is the dominant process supporting new production along this coastline.

\section{ACKNOWLEDGEMENTS}

The authors would like to thank the crews of the research vessels Hespérides and García del Cid for their assistance during the cruises. Cruises were funded under the MAST program FRONTS. We especially would like to thank Tom Hopkins and Jordi Salat for their helpful comments while reviewing this paper.

\section{REFERENCES}

Alvarez, A., J. Tintoré and A. Sabatés. -1996. Flow modification and shelf-slope exchange induced by a submarine canyon off the northeast Spanish coast. J. Geophys. Res., 101(C5): 12,04312,055 .

Castellón, A., J. Font and E. García. - 1990. The liguro-provençalcatalan current (NW Mediterranean) observed by Doppler profiling in the Balearic Sea. Sci. Mar., 54(3): 269-276.

Cushman-Roisin. - 1994. Introduction to Geophysical Fluid Dynamics. Prentice Hall, Englewood Cliffs, New Jersey.

Estrada, M. - 1979. Observaciones sobre la heterogeneidad del fitoplancton en una zona costera del mar Catalán. Inv. Pesq., 43(3): 637-666.

Estrada, M. - 1982. Phytoplankton of the western Mediterranean at the beginning of Autumn. Int. Revue ges. Hydrobiol., 67: 517532.

Estrada, E. - 1993. Hydrographic structure and primary production in oligotrophic marine environments. In: R. Guerrero and C. Pedrós-Alió (eds.), Trends in Microbial Ecology - Community Ecology, pp. 453-458. Spanish Society for Microbiology.

Estrada, M. and R. Margalef. - 1988. Supply of nutrients to the Mediterranean photic zone along a persistent front. Oceanol. Acta, SP: 133-142.

Estrada, M. and J. Salat. - 1989. Phytoplankton assemblages of deep and surface water layers in a Mediterranean frontal zone.
Sci. Mar., 53 (2-3): 203-214.

Estrada, M., C. Marrasé, M. Latasa, E. Berdalet, M. Delgado and T. Riera. - 1993. Variability of deep chlorophyll maximum characteristics in the Northwestern Mediterranean. Mar. Ecol. Prog. Ser., 92: 289-300.

Font, J., J. Salat and A. Julià. - 1990. Marine circulation along the Ebro continental margin. Mar. Geol., 95: 165-177.

Font, J., E. García-Ladona and E.G. Górriz. -1995. The seasonality of mesoscale motion in the northern current of the Western Mediterranean: several years of evidence. Oceanol. Acta, 18 (2): 207-218.

Granata, T.C., J. Wiggert and T. Dickey. -1995. Observations of trapped near-inertial waves and their effects on chlorophyll distributions. J. Geophys. Res., 100(C10): 20,793-20,804.

Granata, T., B. Vidondo, C. Duarte, P. Satta and M. García. - 1999. Hydrodynamics and particle transport associated with a submarine canyon off Blanes (Spain) NW Mediterranean Sea. Contin. Shelf Res., 19: 1249-1263.

La Violette, P.E., J. Tintoré and J. Font. - 1990. The surface circulation of the Balearic Sea. J. Geophys. Res., 95(C2): 15591568.

López García, M.J. - 1991. La temperatura del mar balear a partir de imágenes de satélite. Ph.D. thesis, Universidad de Valencia, Departemento de Geografía. Spain.

Masó, M., P.E. la Violette and J. Tintoré. - 1990. Coastal flow modification by submarine canyons along the NE Spanish coast. Sci. Mar., 54(4): 343-348.

Masó, M. and J. Tintoré. - 1991. Variability of the shelf water off the northeast Spanish coast. J. Mar. Syst., 1: 441-450.

Olivar, M.P., A. Sabatés, P. Abelló and M.A. García. - 1998. Transitory hydrographic structures and distribution of fish larvae and neustonic crustaceans in the north-western Mediterranean. Oceanol. Acta, 21(1): 95-104.

Onken, R. - 1992. Mesoscale upwelling and density fine structure in the seasonal thermocline - a dynamical model. J. Phys. Oceanogr., 22: 1257-1273.

Pinot, J.-M., J. Tintoré, J.L. López-Jurado, M.L. Fernández de Puelles and J. Jansà. - 1995. Three-dimensional circulation of a mesoscale eddy/front system and its biological implications. Oceanol. Acta, 18(4): 389-400.

Pinot, J.-M., J. Tintoré and D.-P. Wang. - 1996. A study of the omega equation for diagnosing vertical motions at ocean fronts. J. Mar. Res., 54: 239-259.

Rojas, P., M.A. García, J. Sospendra, J. Figa, J. Puigdefàbregas, O. López, M. Espino, V. Ortiz, A. Sánchez-Arcilla, M. Manríquez and B. Shirasago. - 1995. On the structure of the mean flow in the Blanes Canyon area (NW Mediterranean) during summer. Ocean. Acta, 18(4): 443-454.

Sabatés, A., J. Salat and M.P. Olivar. - 2001. Advection of continental water as an export mechanism for anchovy, Engraulis encrasicolus, larvae. Sci. Mar., 65(Suppl. 1): 77-87.

Salat, J. and J. Font. - 1987. Water mass structure near and offshore the Catalan coast during the winters of 1982 and 1983. Annal. Geophys., 5B: 49-54.

Salat, J., J. Tintoré, J. Font, D.-P. Wang and M. Vieira. - 1992. Near-inertial motion on the shelf-slope front off northeast Spain. J. Geophys. Res., 97(C5): 7277-7281.

Salat, J., M.A. García, A. Cruzado, A. Palanques, L. Arín, D. Gomis, J. Guillén, A. de León, J. Puigdefàbregas, J. Sospendra and Z.R. Velásquez. - 2002. Seasonal changes of water mass structure and shelf slope exchanges at the Ebro Shelf (NW Mediterranean). Contin. Shelf Res., 22: 327-348.

Tintoré, J., D.-P. Wang and P.E. La Violette. - 1990. Eddies and thermohaline intrusions of the shelf/slope front off the northeast Spanish coast. J. Geophys. Res., 95(C2): 1627-1633.

Wang, D.-P., M.E.C. Vieira, J. Salat, J. Tintoré and P.E. La Violette. - 1988. A shelf/slope frontal filament off the northeast Spanish coast. J. Mar. Res., 46: 321-332.

Wiggert, J., T. Dickey and T. Granata. - 1994. The effect of temporal under sampling on primary production estimates. J. Geophys. Res., 99, 3361-3371.

Zakadjian, B. and L. Prieur. - 1998. Biological and chemical signs of upward motions in permanent geostrophic fronts of the Western Mediterranean. J. Geophys. Res., 103(C12): 27,84927,866 .

Zika, U. - 1999. Factors affecting settlement and post-settlement processes in littoral marine fishes, focusing on Aidablennius sphynx. Diss. No. 13241, ETH Zürich. 
